\title{
Geochemistry, mineralogy and depositional environment of black shales of the Duwi Formation, Qusseir area, Red Sea coast, Egypt
}

\author{
Esmat A. Abou El-Anwar ${ }^{1}$ - H. S. Mekky ${ }^{1}$ W. Abdel Wahab ${ }^{1}$
}

Accepted: 22 December 2017 / Published online: 30 January 2018

(c) The Author(s) 2018. This article is an open access publication

\begin{abstract}
This study focuses on the geochemistry of redox-sensitive elements of marine black shales at the Qusseir area of the Duwi Formation to infer their depositional environment. The black shales from the uppermost member of the Duwi Formation in the Qusseir area is conformably overlain by the Qusseir variegated shale and underlain by the Dakhla shale. Detailed mineralogical and geochemical characteristics were examined using several techniques, including X-ray diffractometry, scanning electron microscopy and X-ray fluorescence. Mineralogically, black shales in the Duwi Formation are composed mainly of montmorillonite, kaolinite, calcite, gypsum, quartz and pyrite. They are detrital and authigenic in origin. They are most probably derived from basic volcanic rocks by intensive chemical weathering under the prevalence of semiarid conditions. The redox-sensitive trace metals suggest anoxic sulfidic conditions that favoured the accumulation of these metals in the Qusseir area of the Duwi Formation.
\end{abstract}

Keywords Geochemistry · Redox-trace elements · Qussier · Anoxic-sulfidic

\section{Introduction}

Cretaceous-Paleocene organic-rich sediments in Egypt extend from the Qusseir-Safaga district (Red Sea) to the Kharga-Dakhla (Western Desert) province. The Upper Cretaceous layer is dominated by black shale and marl facies with limestone, phosphorite and glauconite interbeds. The Duwi Formation consists of interbedded shales, marls, reefal-limestone and phosphate lenticular bands. It unconformably overlies the Quseir Formation and underlies the Dakhla Formation. Most published works classify the Duwi Formation into three members: the lower phosphate member (Late Campanian) and the middle and upper phosphate members (Early Maastrichtian). Qusseir carbonaceous shales consist predominantly of banded clay with disseminated carbonaceous matter and shells of foraminefera. The black shale beds have many equivalents in the Middle East-North African phosphogenic province (cf. Yoffe et al. 2002). Most researchers adopt a marine model for the deposition of the black shales in this province (Baioumy and Tada 2005; Abou

Esmat A. Abou El-Anwar

abouelanwar2004@yahoo.com

1 Geological Sciences Department, National Research Center, Giza, Egypt
El-Anwar et al. 2014; Abou El-Anwar 2016; El-Shafeiy et al. 2016 and Abou El-Anwar et al. 2017). This is consistent with the observation that these sediments are enriched with organic matter resulting from high surface paleoproductivity accompanied by high nutrient levels and oxygen poor bottom water during the Late Campanian-Early Maastrichtian (Baioumy and Tada 2005; Schneider-Mor et al. 2012). The carbon, hydrogen, nitrogen, ash contents, and gross calorific values are similar to those of Volga inflammable shales mined in the U. S. S. R. The ash is rich in calcium oxide content and could be employed in civil engineering. The Qusseir carbonaceous shales have high sulfur and volatile sulfur contents. The amount of organic matter, $22 \%$ kerogen in Qusseir's carbonaceous shale, is comparable to the shales mined in Colorado, USA.

Organic matter and some trace metals are transferred to the seafloor under anoxic conditions and can result in considerable trace metal concentrations in seawater (Ross and Bustin 2009). Consequently, the organic-rich sediments may be enriched in redox-sensitive metals, in $\mathrm{U}, \mathrm{Cu}$ and $\mathrm{Ni}$ and insoluble sulfides such as $\mathrm{Mo}, \mathrm{V}, \mathrm{Cd}, \mathrm{Zn}$ and occasionally $\mathrm{Co}$ (Brumsack 2006; Marz 2007; Hetzel et al. 2009). The black shales usually contain high concentrations of redox-sensitive trace elements (Brumsack 2006; Loukola-Ruskeeniemi and 
Lahtinen 2013; Smrzka et al. 2017 and El-Shafeiy et al. 2017).

This study focuses on the geochemistry of redox-sensitive elements of marine black shales at the Qussier area of the Duwi Formation to infer their depositional environment.

\section{Geologic setting}

Black shales are intercalated with phosphorites of the Duwi Formation in the Qusseir-Safaga area, on the Red Sea coast. The Duwi Formation overlies the fluvial shale series of the Qusseir Formation and underlies the deeper marine shales and marls of the Dakhla Formation (Fig. 1). Therefore, the Duwi Formation in Egypt represents the early period of the Late Cretaceous marine transgression. Baioumy and Tada (2005) subdivided the Duwi Formation, based on its lithology, into four members (Fig. 2). The upper member (3-30 m) consists of yellowish-grey, parallel to cross-laminated, oyster fragment-rich calcarenite with thin intercalations of siltstone, shale, chert, and phosphorite.

The chosen area is represented by the El- Beida and Nakheil mines (Fig. 1). They occur in the upper member of Duwi Formation in Qusseir region (Fig. 2). Nakheil mines are located $18 \mathrm{~km}$ north of Qusseir and $20 \mathrm{~km}$ east of the Yonis mines, and are situated to the east of Gebel Duwi, located at longitudes $34^{\circ} 2^{\prime} 50^{\prime \prime}-34^{\circ} 03^{\prime} 10^{\prime \prime} \mathrm{E}$ and latitudes $26^{\circ} 11^{\prime} 12^{\prime \prime}-26^{\circ} 11^{\prime} 27^{\prime \prime} \mathrm{N}$. These mines represent some of the largest phosphate mines in the Qusseir region of the Red Sea. Also, Nakheil phosphate ore is one of the purest

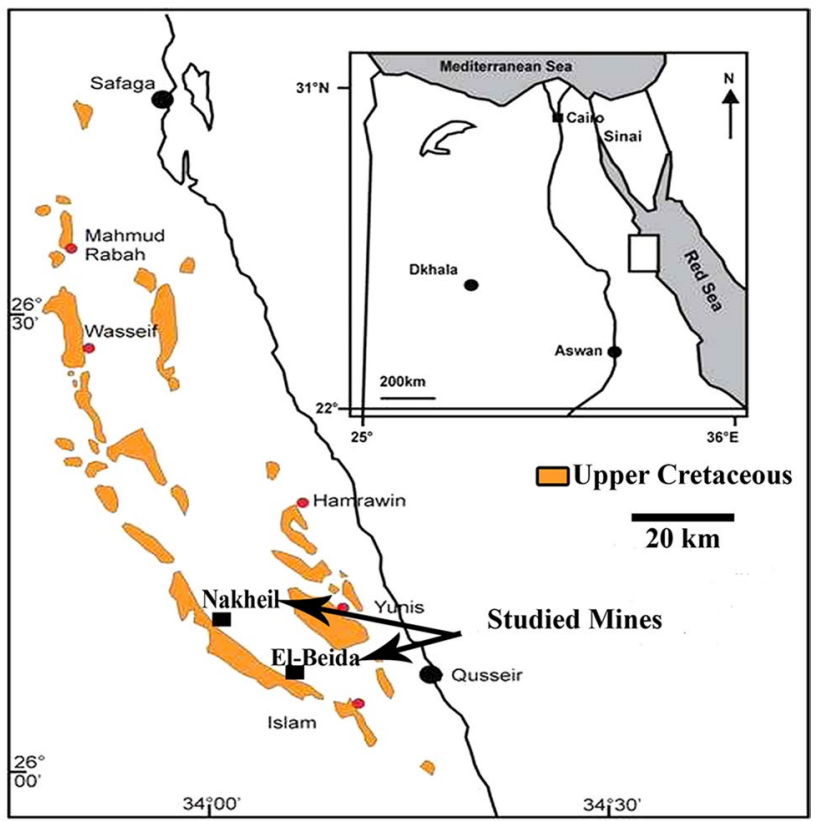

Fig. 1 The location map of the studied mines

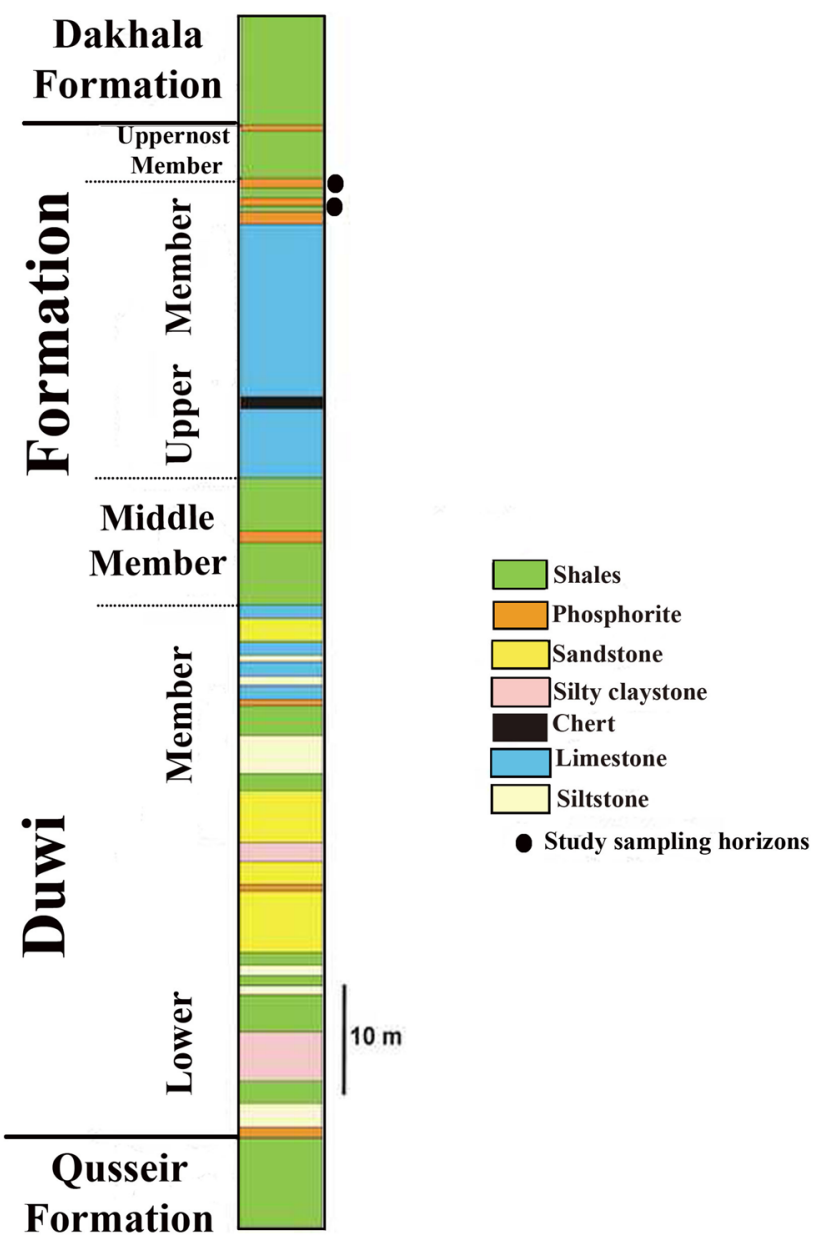

Fig. 2 Stratigraphic columnar section of the Duwi Formation in the Red Sea area showing the stratigraphic site of the black shale beds (after Baioumy and Tada 2005)

phosphate ores in Qusseir. The raw ore occurs in horizontal layers extending for several kilometers under the rail tunnels. Phosphate ore is found above a layer of oily black shales. The layers of the black shales are fissile and cohesive, which is distinct from the other the black shales in the area. The El-Bedia mines present at the limestone of Gebel Duwi. The phosphate rocks overlie fissile black shales. The studied area is located at longitudes $34^{\circ} 05^{\prime} 16^{\prime \prime}-34^{\circ} 05^{\prime} 21^{\prime \prime} \mathrm{E}$ and latitudes $26^{\circ} 6^{\prime} 27^{\prime \prime}-26^{\circ} 6^{\prime} 37^{\prime \prime} \mathrm{N}$.

\section{Sampling and methodology}

Twelve representative samples were collected from the shale beds of the El-Beida and Nakheil mines in the south part of the Qusseir. Four selected samples were investigated mineralogically by the X-ray technique at the Egyptian Mineral Resources Authority (Dokki, Egypt) using a PAN analytical 
X-ray Diffraction device, model X'Pert PRO with Secondary Monochromator. Cu-radiation $(\lambda=1.542 \AA)$ at $45 \mathrm{~K}$.V., 35 M.A. and scanning speed $0.02 \%$ were used. The diffraction charts and relative intensities were obtained and compared with ICDD files. The morphology and the size of the synthesized samples were characterized via SEM coupled with energy-dispersive spectroscopy EDAX (SEM Model Quanta FEG 250), carried out in the National Research Center laboratories. Eight samples were selected to determine the chemical composition by using an Axios Sequential WD_XRF Spectrometer, Analytical 2005 in the National Research Center laboratories, with reference to the ASTM E 1621 standard guide for elemental analysis by wavelength dispersive X-ray fluorescence spectrometer and ASTM D 7348 standard test methods for loss on ignition (LOI) of solid combustion.

\section{Mineralogy}

X-ray patterns revealed that the dominant clay minerals in the studied samples are mainly montmorillonite, minor kaolinite and non-clay including calcite, quartz and gypsum (Fig. 3). The predominant montmorillonite is most probably Na-montmorillonite, as indicated from XRD (20 6.75 and $12.58 \mathrm{~d}$-spacing), which is comparable to the bentonite composition ( $2 \theta 6.96$ and $12.67 \mathrm{~d}$-spacing). The abundance of montmorillonite refers to deposition under a marine environment, and is suggestive of a warm/humid climate (Singer 1980; Yuretich et al. 1999). The presence of calcite

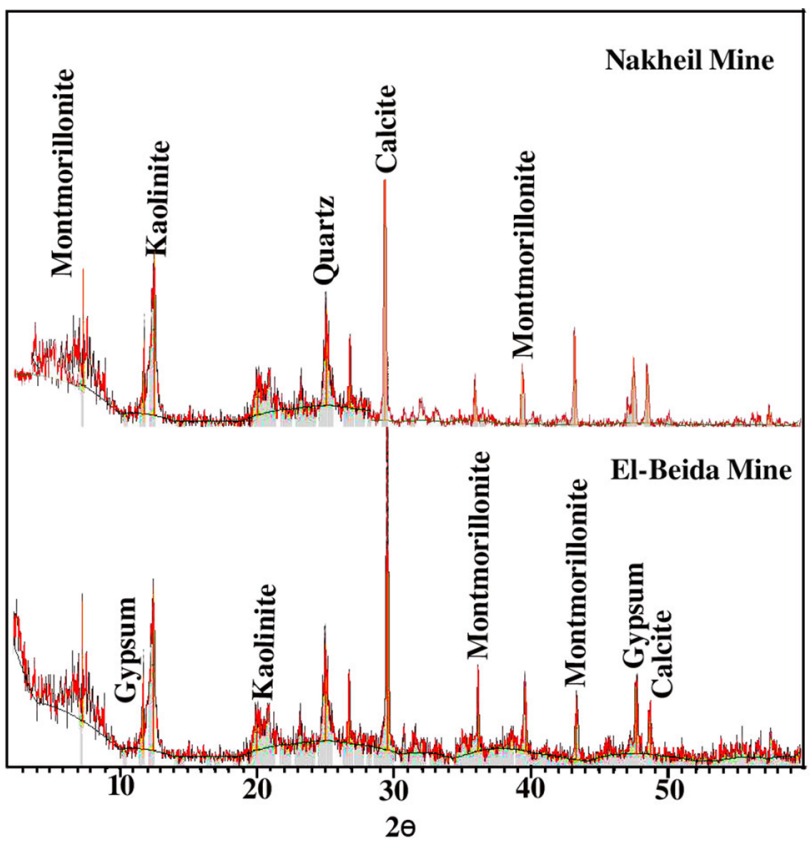

Fig. 3 X-ray diffractograms for the black shales of the studied mines in the studied samples may indicate that the deposition of these shales was in a marine environment. SEM examination of the shale samples confirmed the dominance of montmorillonite. The montmorillonite occurs with detrital and authigenic origin (Fig. 4). Pyrites occur as framboids, are extensively pseudomorphosed and are formed authigenically (Fig. 4). The framboids $(5 \mu \mathrm{m})$ indicate the prevalence of reducing conditions during the deposition (Abou El-Anwar and El-Sayed 2008 and Abou El-Anwar et al. 2017). Pyrite as spheres may indicating shallow water in submarine shelf settings (Schieber and Baird 2001).

\section{Geochemistry}

\section{Results}

The major, trace and rare earth chemical compositions within the entire Nakheil and El-Beida mines in the Qusseir area, along with their ratios, are shown in Table 1, while the interrelationship between major and trace are given in Table 2.

The major elements $\mathrm{SiO}_{2}, \mathrm{Al}_{2} \mathrm{O}_{3}$ and $\mathrm{Fe}_{2} \mathrm{O}_{3}$ (average $26.33,14.34$ and $8.18 \%$; respectively) are highly enriched for the studied El-Beida black shales samples compared to those of the Nakheil samples (18.34, 5.29 and 1.65\%; respectively) Fig. (5). The Nakheil samples are highly enhanced in $\mathrm{CaO}$, $\mathrm{SO}_{3}$ and $\mathrm{P}_{2} \mathrm{O}_{3}$ (average 20.57, 7.43 and 3.24\%; respectively), Fig. (5). The shales in all of the Qusseir mines are relatively depleted in $\mathrm{MgO}, \mathrm{NaO}_{2}, \mathrm{~K}_{2} \mathrm{O}$ and $\mathrm{TiO}_{2}(1.06,0.5,0.81$ and $0.43 \%$; respectively), Table 1 .

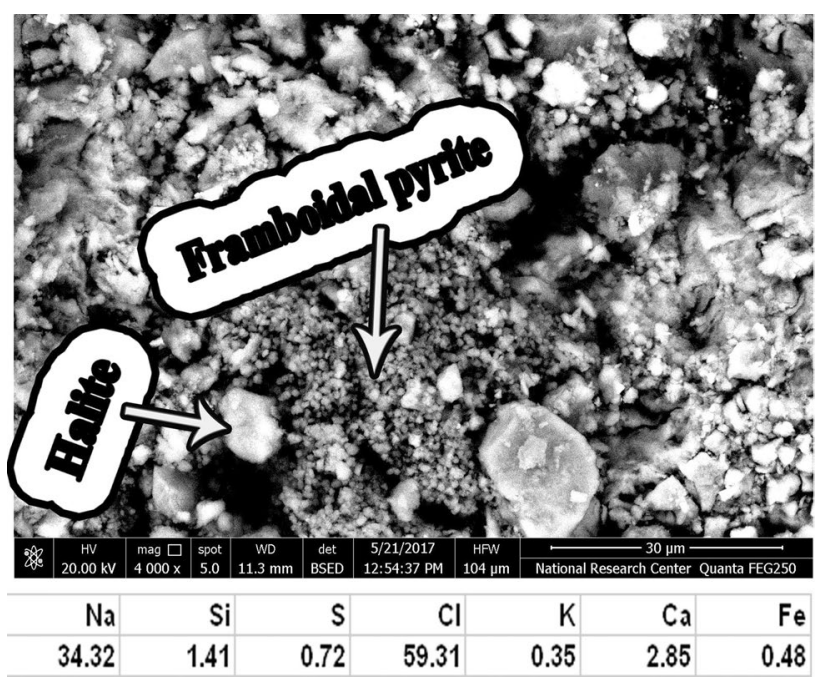

Fig. 4 BSE image and EDX analysis data showing a well crystallized montmorillonite with well developed morphology, spheres of framboidal pyrite (authigenic) and embedded halite aggregate crystals, (El Bedia mine) 
Table 1 XRF data major (\%), trace and rare earth elements (ppm), elemental ratios and CIA of selected studied samples in the black shales of Qusseir

\begin{tabular}{|c|c|c|c|c|c|c|c|c|c|c|c|}
\hline Element & El-Beida 1 & El-Beida 2 & El-Beida 3 & El-Beida 4 & Nakh. 1 & Nakh. 2 & Nakh. 3 & Nakh. 4 & Min. & Max. & Average \\
\hline $\mathrm{SiO}_{2}$ & 29.95 & 30.87 & 20.25 & 24.24 & 19.32 & 17.32 & 16.8 & 19.8 & 16.8 & 30.87 & 22.32 \\
\hline $\mathrm{Al}_{2} \mathrm{O}_{3}$ & 17.37 & 15.52 & 11.21 & 13.25 & 5.01 & 6.01 & 4.92 & 5.2 & 4.92 & 17.37 & 9.81 \\
\hline $\mathrm{P}_{2} \mathrm{O}_{5}$ & 0.94 & 0.66 & 1.32 & 1.52 & 2.93 & 3.93 & 3.71 & 2.4 & 0.66 & 3.93 & 2.18 \\
\hline $\mathrm{TiO}_{2}$ & 0.58 & 0.76 & 0.54 & 0.65 & 0.22 & 0.21 & 0.22 & 0.23 & 0.21 & 0.76 & 0.43 \\
\hline $\mathrm{CaO}$ & 15.1 & 14.42 & 23.51 & 18.25 & 18.22 & 20.21 & 21.85 & 22.01 & 14.42 & 23.51 & 19.20 \\
\hline $\mathrm{MgO}$ & 1.04 & 1.44 & 1.34 & 1.61 & 0.79 & 0.79 & 0.85 & 0.65 & 0.65 & 1.61 & 1.06 \\
\hline $\mathrm{Fe}_{2} \mathrm{O}_{3}$ & 8.13 & 7.77 & 7.91 & 8.91 & 1.66 & 1.62 & 1.81 & 1.52 & 1.52 & 8.91 & 4.92 \\
\hline $\mathrm{Na}_{2} \mathrm{O}$ & 0.51 & 1.14 & 0.91 & 0.85 & 0.17 & 0.16 & 0.15 & 0.14 & 0.14 & 1.14 & 0.50 \\
\hline $\mathrm{K}_{2} \mathrm{O}$ & 0.78 & 0.93 & 1.21 & 1.84 & 0.44 & 0.43 & 0.45 & 0.41 & 0.41 & 1.84 & 0.81 \\
\hline $\mathrm{SO}_{3}$ & 2.07 & 2.64 & 3.01 & 2.84 & 7.69 & 7.96 & 7.85 & 6.21 & 2.07 & 7.96 & 5.03 \\
\hline $\mathrm{SrO}$ & 0.11 & 0.11 & 0.24 & 0.19 & 0.073 & 0.05 & 0.06 & 0.05 & 0.05 & 0.24 & 0.11 \\
\hline $\mathrm{Cl}$ & 0.29 & 0.87 & 0.81 & 0.54 & 0.05 & 0.03 & 0.04 & 0.04 & 0.03 & 0.87 & 0.33 \\
\hline $\mathrm{Mn}$ & 349 & 279 & 315 & 295 & 400 & 310 & 500 & 350 & 279 & 500 & 349.75 \\
\hline Mo & 158 & 130 & 146 & 160 & 547 & 570 & 510 & 420 & 130 & 570 & 330.13 \\
\hline $\mathrm{Pd}$ & 74 & 60 & 65 & 55 & 9 & 12 & 14 & 10 & 9 & 74 & 37.38 \\
\hline $\mathrm{Ba}$ & 72 & 99 & 85 & 77 & 90 & 75 & 80 & 71 & 71 & 99 & 81.13 \\
\hline $\mathrm{Cr}$ & 431 & 233 & 343 & 390 & 977 & 1024 & 1240 & 1190 & 233 & 1240 & 728.50 \\
\hline $\mathrm{Cu}$ & 65 & 54 & 31 & 34 & 289 & 130 & 272 & 250 & 31 & 289 & 140.63 \\
\hline $\mathrm{Ni}$ & 140 & 95 & 87 & 64 & 267 & 270 & 255 & 190 & 64 & 270 & 171.00 \\
\hline $\mathrm{Zr}$ & 89 & 119 & 130 & 155 & 60 & 55 & 25 & 50 & 25 & 155 & 85.38 \\
\hline $\mathrm{V}$ & 920 & 452 & 140 & 621 & 1095 & 2010 & 1750 & 1920 & 140 & 2010 & 1113.50 \\
\hline $\mathrm{Zn}$ & 185 & 193 & 210 & 180 & 1510 & 2320 & 1950 & 2058 & 180 & 2320 & 1075.75 \\
\hline $\mathrm{Cd}$ & 10 & 8 & 6 & 5 & 166 & 200 & 210 & 150 & 5 & 210 & 94.38 \\
\hline $\mathrm{Rb}$ & 52 & 9 & 20 & 25 & 34 & 25 & 30 & 27 & 9 & 52 & 27.75 \\
\hline $\mathrm{Y}$ & 20 & 4 & 16 & 15 & 8 & 6 & 7 & 8 & 4 & 20 & 10.50 \\
\hline $\mathrm{Ga}$ & 22 & 23 & 20 & 25 & 7.2 & 6 & 4.5 & 5.5 & 4.5 & 25 & 14.15 \\
\hline As & 30 & 43 & 25 & 18 & 85 & 65 & 70 & 81 & 18 & 85 & 52.13 \\
\hline $\mathrm{Se}$ & 20 & 24 & 23 & 19 & 6.4 & 4.7 & 5.1 & 5.4 & 4.7 & 24 & 13.45 \\
\hline $\mathrm{Br}$ & 40 & 50 & 25 & 44 & 90 & 72 & 81 & 77 & 25 & 90 & 59.88 \\
\hline $\mathrm{Nb}$ & 7 & 17 & 8.5 & 10 & 3 & 2.5 & 1.2 & 2.4 & 1.2 & 17 & 6.45 \\
\hline $\mathrm{U}$ & 90 & 74 & 61 & 41 & 40 & 35 & 20 & 35 & 20 & 90 & 49.50 \\
\hline L.I.O & 22.95 & 22.72 & 27.71 & 25.29 & 42.57 & 41.81 & 41.27 & 41.31 & 22.72 & 42.57 & 33.20 \\
\hline V/Mo & 5.82 & 3.48 & 0.96 & 3.88 & 2.00 & 3.53 & 3.43 & 4.57 & 0.96 & 5.82 & 3.37 \\
\hline $\mathrm{V} / \mathrm{Ni}$ & 6.57 & 4.76 & 1.61 & 9.70 & 4.10 & 7.44 & 6.86 & 10.11 & 2.19 & 7.44 & 6.51 \\
\hline $\mathrm{V} /(\mathrm{V}+\mathrm{Ni})$ & 0.87 & 0.83 & 0.62 & 0.91 & 0.80 & 0.88 & 0.87 & 0.91 & 0.69 & 0.88 & 0.87 \\
\hline $\mathrm{V} /(\mathrm{V}+\mathrm{Cr})$ & 0.68 & 0.66 & 0.29 & 0.61 & 0.53 & 0.66 & 0.59 & 0.62 & 0.38 & 0.62 & 0.61 \\
\hline $\mathrm{Mo} / \mathrm{U}$ & 1.76 & 1.76 & 2.39 & 7.20 & 13.68 & 16.29 & 14.57 & 12.00 & 1.76 & 16.29 & 8.70 \\
\hline U/Mo & 0.57 & 0.57 & 0.42 & 0.26 & 0.07 & 0.06 & 0.04 & 0.08 & 0.15 & 0.16 & 0.15 \\
\hline $\mathrm{Rb} / \mathrm{Sr}$ & 0.096 & 0.009 & 0.009 & 0.015 & 0.102 & 0.059 & 0.058 & 0.063 & 0.009 & 0.102 & 0.05 \\
\hline $\mathrm{Fe} / \mathrm{Ti}$ & 14.02 & 10.22 & 14.65 & 13.71 & 7.55 & 7.71 & 8.23 & 6.61 & 7.24 & 11.72 & 11.53 \\
\hline CIA & 90.61 & 82.86 & 78.72 & 78.92 & 86.53 & 88.91 & 86.77 & 88.29 & 78.72 & 90.61 & 84.68 \\
\hline
\end{tabular}

The loss of ignition values were recorded (average about 42 and $25 \%$ for Nakheil and El-Bedia mines, respectively) and generally averaged (33.2\%) for the whole area.

The concentrations of $\mathrm{V}, \mathrm{Zn}, \mathrm{Mo}, \mathrm{Pd}, \mathrm{Cr}, \mathrm{Cd}, \mathrm{As}, \mathrm{Y}$, Se and $U$ in the studied samples were higher than those reported by Taylor and McLennan (1985) for Upper Continental Crust (UCC) and those of the Post Archaean Australian Shale (PAAS) recorded by Rudnick and Gao (2003), Fig. 6. The percentages of $\mathrm{Mn}, \mathrm{Ba}, \mathrm{Br}$ and $\mathrm{Nb}$ were lower than those of (UCC) and (PAAS). 
Table 2 Correlation coefficients of the major and trace elements in the studied black shales

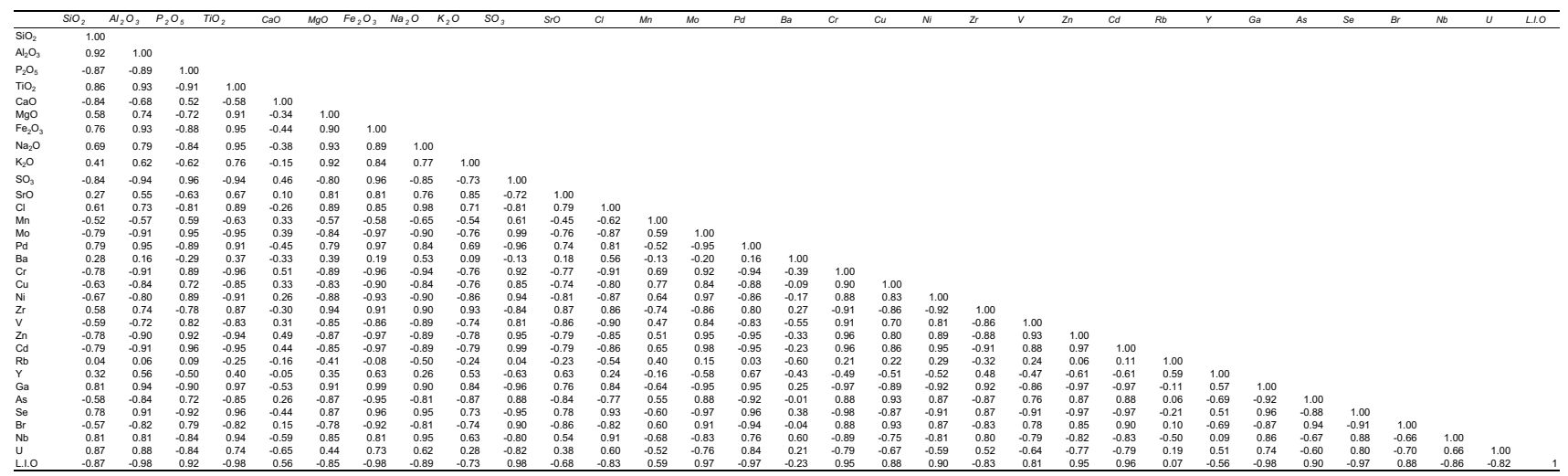

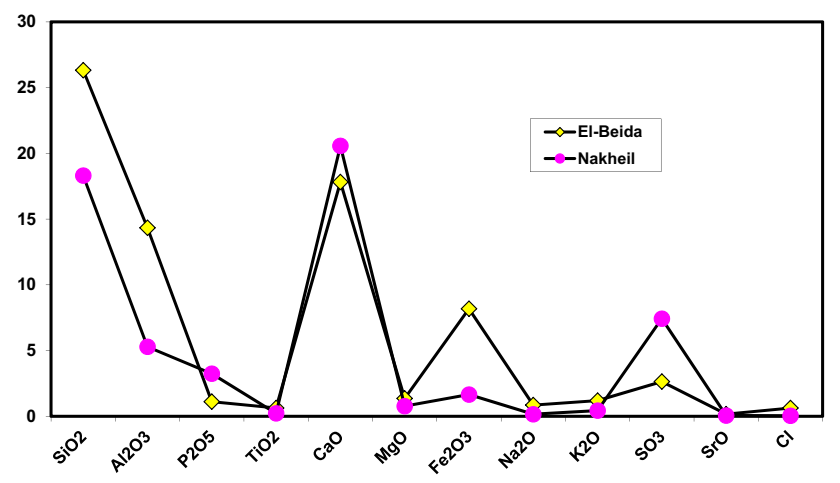

Fig. 5 Concentrations of the major elements in the studied black shales

\section{Discussion}

\section{Major elements}

The high loss of ignition (average about 42 and 25\% for Nakheil and El- Bedia mines, respectively) and average $33.2 \%$ for the whole area revealed the presence of large amounts of organic matter. The microorganisms in black shales revealed the effect of the organic matter during chemical weathering (cf. Blumenberga et al. 2012).

Strong positive correlation $(r=0.92)$ between $\mathrm{SiO}_{2}$ and $\mathrm{Al}_{2} \mathrm{O}_{3}$ revealed that most $\mathrm{Al}_{2} \mathrm{O}_{3}$ is present as clay minerals, which conformed with X-ray diffraction, occurring as well as detrital grains, which conformed with SEM examination. $\mathrm{Fe}_{2} \mathrm{O}_{3}$ values for the studied black shales averaged $4.92 \%$ (Table 1). This concentration may be controlled by hydrothermal leaching or additions of $\mathrm{Fe}$, consistent with reduced fluids. The high positive correlation between $\mathrm{Fe}_{2} \mathrm{O}_{3}$ and $\mathrm{Sr}(r=0.81$, Table 2$)$ indicates that the studied shales were deposited under control of bacterial activity (cf. Abou El Anwar 2005, 2006, 2011, 2014, 2016; Abou El Anwar and Mekky 2013). The strong positive correlation $(r=0.96)$ between $\mathrm{Fe}_{2} \mathrm{O}_{3}$ and total sulfur content indicates that the organic sulfur prevails along with pyrite (cf. Xiugen et al. 2010; Abou El-Anwar 2016).

\section{Trace and rare earth elements}

Black shales in the Nakheil mines are highly enriched in trace $(\mathrm{Zn}=1952, \mathrm{~V}=1694, \mathrm{Cr}=1108, \mathrm{Mo}=390$, $\mathrm{Ni}=246, \mathrm{Cu}=236$ and $\mathrm{Cd}=182 \mathrm{ppm})$ and rare earth elements $(\mathrm{Br}=80, \mathrm{As}=75$ and $\mathrm{Rb}=29 \mathrm{ppm})$ compared
Fig. 6 Concentrations of the trace and rare earth elements in the studied black shales correlated with UCC (Rudnick and Gao 2003) and PAAS (Taylor and McLennan 1985)

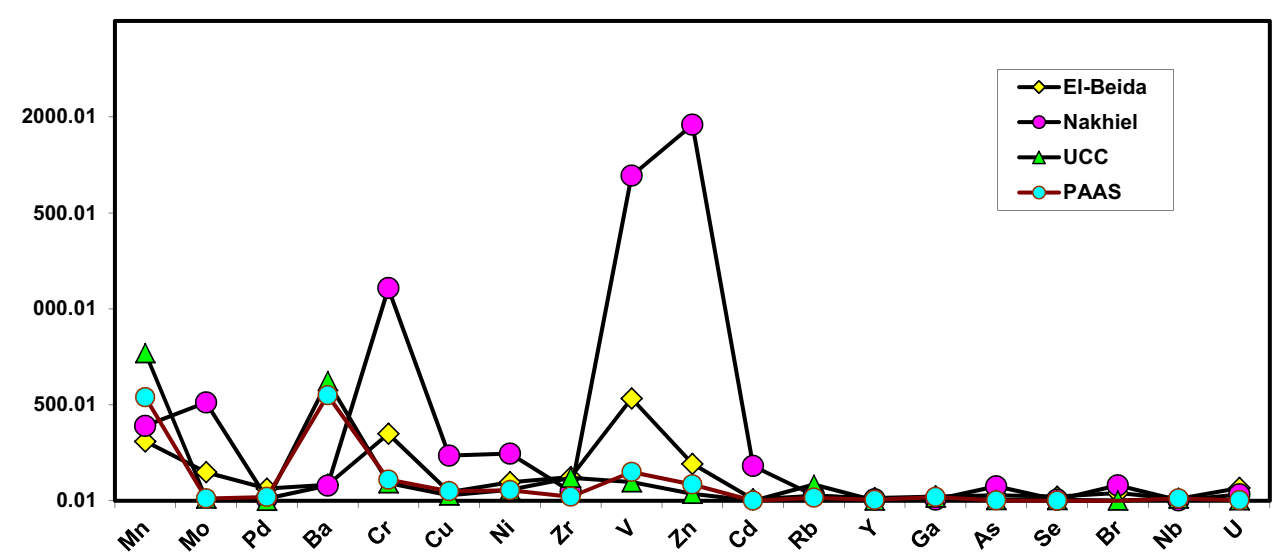




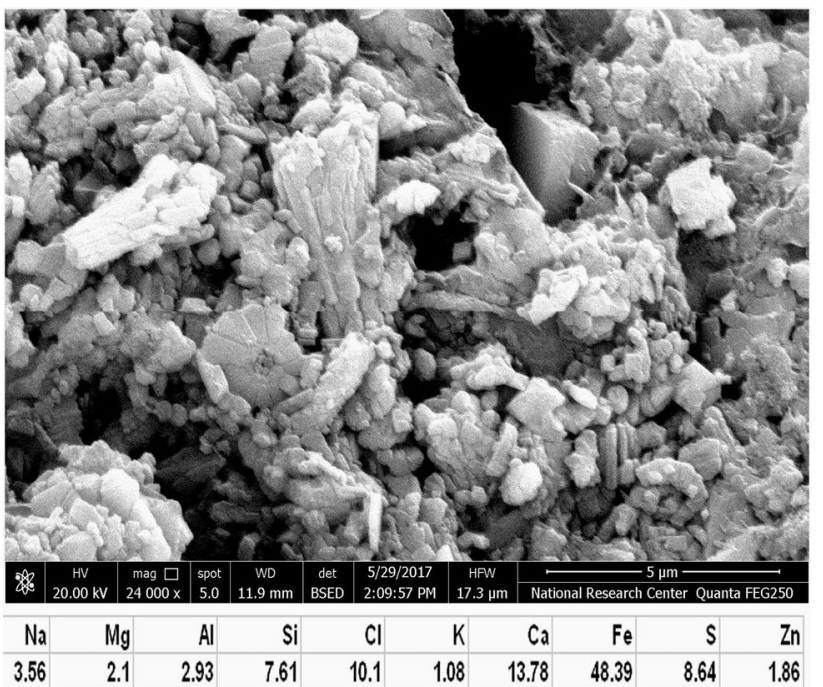

Fig. 7 BSE image and EDX analysis data of fossil (foraminifera), where $\mathrm{Zn}$ content reaches $1.86 \%$. Note aggregate of halite crystals, kaolinite and detrital montmorillonite in Nakheil mine shales

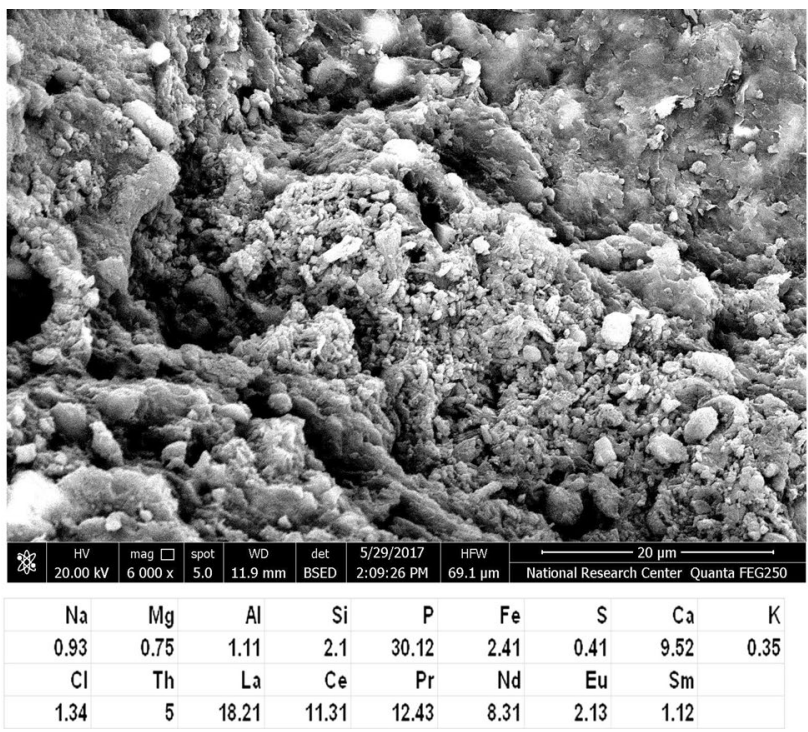

Fig. 8 BSE image and semi quantitative EDX analysis showing dissolution in the clay matrix and data of detrital monazite, Nakheil mine

to those of the El-Beida mines (Fig. 6). The higher average $(\mathrm{Zn}=1952)$ in shales of the Nakheil mines agrees with the obtained EDX data, where foraminifera accumulate high concentrations of $\mathrm{Zn}$ (Fig. 7). Also, these mines are characterized by the presence of detrital of monazite (Figs. 8), in the contributed terrigenous fraction. EDX data show that the analyzed REE abundance is la $>\mathrm{Pr}>\mathrm{Ce}>\mathrm{Nd}>\mathrm{Eu}>\mathrm{Sm}$. Magmatic monazite contains $\mathrm{ThO}_{2}$, ranging from 2 to $13 \%$ (Bea 1996) and from < 1 to 20\% (Forster 1998), representing a pegmatitic source. The EDX data of the studied samples reported a low content of Th and a positive value of $\mathrm{Eu}$, which may indicate that the recorded monazite grains may be related to metamorphic sources (Abu Halawa et al. 2011; Abou El-Anwar 2012). Figure 8 also shows halite crystals. The studied black shales in the El- Beida mines have an enrichment average in $\mathrm{Zr}(124 \mathrm{ppm}), \mathrm{Ba}(85 \mathrm{ppm})$ and $\mathrm{Pd}$ $(64 \mathrm{ppm})$ as trace elements, and rare earth elements, $\mathrm{Ga}$ (23 ppm), Se (22 ppm), Y (14 ppm) and Nb (11 ppm), as well as $\mathrm{U}(67 \mathrm{ppm})$, as shown in Fig. 6.

$\mathrm{Cr}, \mathrm{Cu}, \mathrm{Ni}, \mathrm{V}, \mathrm{Zn}$ and $\mathrm{Cd}$ strongly positively correlated with both $\mathrm{P}_{2} \mathrm{O}_{3}(r=0.89,0.72,0.89,0.82,0.92$ and 0.96; respectively) and $\mathrm{SO}_{3}(r=0.92,0.85,0.94,0.81,0.95$ and 0.99 ; respectively). This indicates that these trace elements are associated with apatite and/or sulphedes minerals. The strong positive relation between $\mathrm{Pd}$ and $\mathrm{SiO}_{2}, \mathrm{Al}_{2} \mathrm{O}_{3}, \mathrm{Fe}_{2} \mathrm{O}_{3}$ and $\mathrm{MgO}(r=0.79,0.95,0.79$ and 0.97 ; respectively) reveals that Pd was associated with clay minerals and ferromagnesian oxides. A high positive relation between loss of ignition and $\mathrm{Mo}, \mathrm{Cr}, \mathrm{Cu}, \mathrm{Ni}, \mathrm{V}, \mathrm{Zn}, \mathrm{Cd}, \mathrm{As}$ and $\mathrm{Br}(r=0.97$, $0.95,0.88,0.90,0.81,0.95,0.96,0.90$ and 0.88 ; respectively), reveals that trace and some rare earth elements may be related to organic matter (Marz 2007; Ross et al. 2009). Trace metals such as $\mathrm{As}, \mathrm{Cu}, \mathrm{Mo}, \mathrm{Ni}, \mathrm{U}, \mathrm{V}$ and $\mathrm{Zn}$ are recognized to be particularly enriched in organic-rich sediments (cf. Marz 2007).

Vanadium is the most abundant trace element in the studied black shale samples, averaging $1114 \mathrm{ppm}$. The higher concentration of $\mathrm{V}$ may be the result of oxidation and weathering of organic matter. Zinc represents the second most abundant trace element in the studied black shale samples (average $1076 \mathrm{ppm}$ ). The higher content of zircon and the negative correlation with L.O.I and high positive with $\mathrm{Al}_{2} \mathrm{O}_{3}$ $\mathrm{Na}_{2} \mathrm{O}, \mathrm{K}_{2} \mathrm{O}$ and $\mathrm{SiO}_{2}(r=-0.87$ and $r=0.74,0.90,0.93$ and 0.58 ; respectively) reveal that it may be incorporated with clay minerals and detrital quartz, not with organic matter. This is also supported from the observed significant positive correlations between $\mathrm{Zr}$ and $\mathrm{TiO}_{2}, \mathrm{Fe}_{2} \mathrm{O}_{3}, \mathrm{Al}_{2} \mathrm{O}_{3}, \mathrm{MgO}$ and $\mathrm{Pd}(r=0.87,0.91,0.74,0.68,0.94$ and 0.80 ; respectively), which reveal that it is mostly coupled with $\mathrm{Fe}-\mathrm{Ti}$ oxides and/or clay fractions. The studied shales contain high concentrations of $\mathrm{Ni}$ (average $171 \mathrm{ppm}$ ) as compared with the corresponding values reported for the UCC and the PAAS (57 and 55 ppm; respectively). Ni is more abundant in deep marine sediments up to $300 \mathrm{ppm}$, whereas its occurrence in coastal sediments is $39 \mathrm{ppm}$ (Turekian 1978). Consequently, the studied black shales were deposited under marine conditions.

There is a high positive correlation between $\mathrm{Al}_{2} \mathrm{O}_{3}$ and rare earth elements $\mathrm{Ga}, \mathrm{Se}, \mathrm{Nb}$ and $\mathrm{Y}(r=0.94,0.91,0.81$ and 0.56; respectively), and they have positive relations with $\mathrm{SiO}_{2}(r=0.81,0.78,0.81$ and 0.32 ; respectively). Thus, the rare earth elements in the studied black shales may be related to clay mineral and/or detrital quartz, not with clay minerals. 
The commonly immobile elements, $\mathrm{Al}, \mathrm{Fe}, \mathrm{Ti}, \mathrm{Cr}, \mathrm{Th}$, $\mathrm{Pd}, \mathrm{Sc}, \mathrm{Co}, \mathrm{Zr}, \mathrm{Nb}, \mathrm{Y}, \mathrm{Ga}$ and $\mathrm{Se}$, are useful markers of provenance, such as weathering, transportation and sorting (Taylor and McLennan 1985). Thus, the strong positive correlations between $\mathrm{Al}_{2} \mathrm{O}_{3}$ and $\mathrm{Cr}, \mathrm{Cu}, \mathrm{Cd}, \mathrm{Pb}, \mathrm{Se}, \mathrm{Ga}, \mathrm{Zr}, \mathrm{Nb}$ and $\mathrm{Y}$, (Table 2) reveal that these elements are concentrated during weathering processes (cf. Fedo et al. 1996).

$\mathrm{U}$ content in the studied black shales range from 20 to $90 \mathrm{ppm}$, thus the study samples can be defined as uraniferous black shales. Most of the uranium in marine black shales was derived from sea water. Uranium could have been precipitated under a hydrogen sulfide environment (Swanson 1961). Thus, the abundance of pyrite in the studied uraniferous shales and the positive correlation between $\mathrm{Fe}_{2} \mathrm{O}_{3}$ and both $\mathrm{SO}_{3}$ and $\mathrm{U}$ ( $r=0.96$ and 0.72 ; respectively), reveal that the high $\mathrm{U}$ contents accumulated in black shales under a hydrogen sulfide environment and gradually increased in diagenetic processes. The U/Mo ratio was applied to distinguish between anoxic non-sulfidic and anoxic sulfidic conditions (cf. Arning et al. 2009). The low U/Mo ratios obtained (average 0.15 , Table 1 ) revealed that the studied uraniferous black shales in Qussier area were deposited under anoxic sulfidic conditions.

\section{Paleo-redox elements and environmental conditions}

The concentration of redox-sensitive elements $(\mathrm{V}, \mathrm{Ni}, \mathrm{Mo}$, $\mathrm{U}, \mathrm{Cu}, \mathrm{Cr}, \mathrm{Re}, \mathrm{Cd}, \mathrm{Sb}, \mathrm{Tl}$, and $\mathrm{Mn}$ ) are indicative of paleooceanographic conditions (Pi et al. 2014 and Adegoke et al. 2014).

High concentrations of Mn (average 56,000 ppm) represent oxic conditions (Quinby-Hunt and Wilde 1994), while less than $260 \mathrm{ppm}$ is considered an anoix environment ( $\mathrm{Pi}$ et al. 2014). The depletion of Mn (average $250 \mathrm{ppm}$ ) in the study samples can possibly be attributed to its relative mobility in its reduced state (cf. Brumsack 2006), where in a minimal oxygen zone $\mathrm{Mn}$ was transported to the open ocean. Mn enrichment is most probably the result of either deposition under dysoxic to oxic conditions or deposition in a closed system (Hetzel et al. 2006). Thus, the depletion of Mn (average $250 \mathrm{ppm}$ ) reveals that the studied black shales deposited under anoxic conditions.

$\mathrm{U}, \mathrm{V}$, and Mo can be used to interpret paleo-redox conditions. These trace metals exhibit different behaviors under various oxygenation conditions. $\mathrm{U}$ and $\mathrm{V}$ may become reduced and accumulate under suboxic to anoxic conditions. On the other hand, Mo has been used as a redox-sensitive proxy for benthic levels (Algeo et al. 2004 and 2006), which becomes enriched mainly under anoxic-sulfidic conditions.

Under reducing conditions, enriched $\mathrm{Mo}$ and $\mathrm{U}$ are deposited authigenically (Algeo and Tribovillard 2009). Thus, the U/Mo ratio can be used to differentiate between suboxic and sulphidic settings. A lower U/Mo ratio (0.15) indicates the sediments of the studied area were deposited under an anoxic marine transgressive environment, which is in agreement with Baioumy and Tada (2005), Abou El-Anwar et al. (2014) and El-Shafeiy et al. (2017).

The accumulation of organic matter played a vital role in the concentration to the sediment of trace metals $\mathrm{Cu}$ and $\mathrm{Ni}$, and the sulphide mineral-forming elements including Mo, $\mathrm{Ni}, \mathrm{U}$ and V (cf. Ross and Bustin 2009). The enrichment of organic matter reveals a period of high primary productivity in a shallow environment conducive to the preservation of organic matter (Glenn and Arthur 1990). Ni can be incorporated into organic matter, and so may be used as a marker for the original presence of organic matter (cf. Tribovillard et al. 2006). Organic-rich sediments are consequently generally enriched in $\mathrm{Cu}$ and $\mathrm{Ni}$, as are the sulphide mineral-forming elements Mo, V, Cd, Zn, U, and rarely Co (Brumsack 2006; Marz 2007; Hetzel et al. 2009). Thus, the high concentration of $\mathrm{Ni}$ content in our samples indicates high productivity and shallow conditions for the Qaussier area.

Ratios of the trace elements can been used to explicate the depositional environment of the black shales. Fe/Ti for the studied shales samples is 11.5 , whichindicates hydrothermal input (cf. Delian et al. 2004).

When V/Mo is close to the seawater ratio $(<2)$, it indicates an anoxic condition; a range from 2 to 10 indicates suboxic conditions, and a ranging from 10 to 60 indicates normal oxygenation (Gallego-Torres et al. 2010). The V/Mo ratio in our samples ranges from 0.96 to 5.83, which indicates that the studied black shales were deposited in anoxic to suboxic conditions.

Under the strong activity of sulfate reducing bacteria in anoxic marine environments, $\mathrm{V}$ is enriched in comparison to $\mathrm{Ni}$ (Peters and Moldowan 1993). Thus, V/Ni can be used to distinguish the level of anoxia during deposition (cf. Galarraga et al. 2008).

A V/Ni ratio $>3$ indicates that organic matter was deposited under marine reducing conditions (Galarraga et al. 2008). V/Ni ranging from 1.9 to 3 indicates deposition under a dysoxic-oxic environment with terrigenous organic matter mixed with marine organic matter. A V/Ni ratio $<1.9$ indicates mainly terrigenous organic matter. The $\mathrm{V} / \mathrm{Ni}$ ratio (average 6.5) in the studied Qussier black shales is greater than 3 (Table 1), revealing that the organic matter in the studied black shales was mainly from marine sources and the shales were deposited under a marine reducing environment. Pi et al. (2014) mentioned that $\mathrm{V} /(\mathrm{V}+\mathrm{Cr})$ ratios of more than 0.6 indicate strongly reducing conditions. $\mathrm{V} /(\mathrm{V}+\mathrm{Cr})$ is 0.61 (Table 1) indicating that the studied samples were precipitated under strongly reducing conditions.

Consequently, the enrichment of redox-sensitive metals (V, Ni, Mo, U, $\mathrm{Cu}, \mathrm{Cr}$, and $\mathrm{Cd}$ ), low Mn contents, strong 
positive correlation between Mo and $\mathrm{V}(r=0.84)$ and $\mathrm{V} /$ Mo ratios, high Ni/Co, $\mathrm{V} /(\mathrm{V}+\mathrm{Ni}), \mathrm{V} /(\mathrm{V}+\mathrm{Cr})$, and $\mathrm{V} / \mathrm{Ni}$ reveal that black shales from the Duwi Formation in the Red Sea area were deposited under marine anoxia environments.

\section{Source of redox-sensitive trace and rare earth elements}

The sources of the trace and rare earth elements may be in marine sedimentary rocks as detrital inputs (Lee 2009), seawater (Piper 1994), organic matter (Piper 1994) or hydrothermal and volcanic activities (Angerera et al. 2013).

Our samples showed a strong positive correlation between L.O.I (mainly organic matter) with $\mathrm{Mo}, \mathrm{Mn}, \mathrm{Cr}, \mathrm{Cu}, \mathrm{V}, \mathrm{Zn}$, $\mathrm{Cd}$, as well as with some rare earth elements, $\mathrm{As}$ and $\mathrm{Br}$, revealing that these elements likely originated from marine organic sources. Correlation between $\mathrm{Fe}_{2} \mathrm{O}_{3}$ and both $\mathrm{SO}_{3}$ and $\mathrm{U}$ reveal that the high $\mathrm{U}$ contents accumulated in black shales under hydrogen sulfide. The high enrichments of certain trace elements, $\mathrm{V}, \mathrm{Cr}, \mathrm{Ni}, \mathrm{As}, \mathrm{Sr}, \mathrm{Mo}$, and $\mathrm{Cd}$, in sedimentary rocks are believed to be related to hydrothermal activity (Angerera et al. 2013). The abundances of $\mathrm{Zn}, \mathrm{Cd}$, $\mathrm{Ni}, \mathrm{Se}, \mathrm{Mo}, \mathrm{Cr}$, and $\mathrm{V}$, much higher than those of PAAS, can be attributed to hydrothermal and/or hydrogenous/biogenic origin. The positive correlation between $\mathrm{SiO}_{2}$ and $\mathrm{Al}_{2} \mathrm{O}_{3}$ with rare earth elements $\mathrm{Ga}, \mathrm{Se}, \mathrm{Nb}$ and $\mathrm{Y}$ suggests detrital input to the Duwi black shales. Consequently, the Duwi Formation in the Qussier area had different sources for redoxsensitive trace and rare earth elements.

\section{Chemical mobility and weathering trends}

The chemical composition of the weathering products in a sedimentary basin are expected to reveal the mobility of various elements during weathering (Singh et al. 2005). CIA provides information on the intensity of chemical weathering that the sediments have undergone (Nesbitt and Young 1982), and is calculated as:

$\mathrm{CIA}=\left[\mathrm{Al}_{2} \mathrm{O}_{3} /\left(\mathrm{Al}_{2} \mathrm{O}_{3}+\mathrm{CaO}^{*}+\mathrm{Na}_{2} \mathrm{O}+\mathrm{K}_{2} \mathrm{O}\right)\right] \times 100$

where $\mathrm{CaO} *$ represents $\mathrm{CaO}$ associated with the silicate fraction of the sample. The CIA values in the studied samples range from 78.72 to 90.61 , averaging $84.68 \%$ (Table 1). This average reveals that the source of the primary minerals was derived from feldspars and/or mafic origins and, generally, represents highly intensive chemical weathering (cf. Nesbitt and Young 1982; Fedo et al. 1995).

$\mathrm{Rb} / \mathrm{Sr}$ ratios can be used to identify the degree of sourcerock weathering (McLennan et al. 1993). The studied shale samples have an average $\mathrm{Rb} / \mathrm{Sr}$ ratio of 0.051 (Table 1). This value is lower than that of the UCC average $(0.33)$ and is relatively comparable to PAAS $(0.08)$. This suggests that the degree of the chemical weathering of the source rocks was relatively comparable to the PAAS values.

\section{Conclusions}

The black shales in the Qusseir area (Duwi Formation, Campanian-Maastrichtian) were deposited in an anoxic marine environment, and are remarkably high in their enrichment of redox-sensitive and sulfide-forming trace metals. Measurements of Mn, U, V, and Mo reveal that the studied black shales deposited under shallow anoxic-sulfidic conditions.

High enrichment of redox-sensitive trace metals $(\mathrm{V}, \mathrm{Ni}$, $\mathrm{Mo}, \mathrm{U}, \mathrm{Cu}, \mathrm{Cr}$, and $\mathrm{Cd})$ and $\mathrm{V} / \mathrm{Ni}, \mathrm{Ni} / \mathrm{Co}, \mathrm{V} /(\mathrm{V}+\mathrm{Ni})$ and $\mathrm{V} /(\mathrm{V}+\mathrm{Cr})$ ratios, low $\mathrm{Mn}$ contents and $\mathrm{V} / \mathrm{Mo}$ ratios, as well as a positive correlation between Mo and V, indicate that sediments of the Campanian-Maastrichtian Tethys were deposited under reducing environments.

The values of the chemical index of alteration (CIA) and the chemical analysis data indicate that the shales were subjected to intense chemical weathering.

Thus, the enrichment of redox-sensitive elements of the Red Sea marine black shales can be considered as strong evidence for anoxic conditions existing during the deposition of the shales of the Qusseir area of the Duwi Formation, and that the redox-sensitive trace and rare earth elements they contain came from different sources.

Open Access This article is distributed under the terms of the Creative Commons Attribution 4.0 International License (http://creativecomm ons.org/licenses/by/4.0/), which permits unrestricted use, distribution, and reproduction in any medium, provided you give appropriate credit to the original author(s) and the source, provide a link to the Creative Commons license, and indicate if changes were made.

\section{References}

Abou El-Anwar EA (2005) Petrography, geochemistry and genesis of the Upper Eocene carbonate terraces (II and III) Qasr El-Sagha Formation, El-Faiyum, Egypt. Sediment Egypt 13:243-260

Abou El-Anwar EA (2006) Petrography, geochemistry and genesis of some Middle Eocene rocks at Qattamia area, Cairo-Suez road Egypt. NRC Egypt 31(6):519-543

Abou El-Anwar EA (2011) Petrographical, geochemical and diagenetic studies of the middle eocene carbonates, mokattam formation of Darb El-Fayium area, In: Int. Conf. on Geological Sciences and Engineering, France, Paris, 80, 1315-1325, Augustus 24-26

Abou El-Anwar EA (2012) Contribution to the composition and origin of the reef terraces in Ras Mohamed, Sharm El-Sheikh Coast, Southern Sinai Egypt. Geol Egypt 56:33-48

Abou El-Anwar EA (2014) Composition and origin of the dolostones of Um Bogma formation, Lower Carboniferous, west central 
Sinai, Egypt. Carbonates Evaporates. https://doi.org/10.1007/ s13146-014-0188-3

Abou El-Anwar EA (2016) Mineralogical, petrographical, geochemical, diageneses and provenance of the Cretaceous black shales, Duwi Formation at Quseir-Safaga, Red Sea, Egypt. Egypt J Petroleum 25:323-332

Abou El-Anwar EA, El-Sayed MS (2008) Composition of black shale from Quseir, Red Sea, Egypt with emphasis on the sequential extraction of some metals. Bull NRC Egypt 32(109):131

Abou El-Anwar EA, Mekky HS (2013) Contribution to the geochemistry, composition and origin of the dolostones of Um Gheig formation, middle Miocene, Red Sea Coast, Egypt. J Appl Sci Res 9(6):3659-3673

Abou El-Anwar EA, Mekky HS, Samy YM (2014) Contribution to the mineralogical, geochemical and provenance of the Cretaceous black shales, Duwi Formation, Quseir-Safaga, Red Sea Coast Egypt. Egypt J Geol 58:303-322

Abou El-Anwar EA, Abd El Rahim SH, Mekky HS (2017) Spherulitic dahllite of Duwi Formation phosphorite. Carbonates Evaporites. https://doi.org/10.1007/s13146-017-0377-y

Abu Halawa A, El-Sankary M, Kandil M (2011) Mineralogy and geochemistry of monazite from Rosetta Black Sands, Nile Delta, Egypt. Sedimentol Egypt 19:55-67

Adegoke AK, Abdullah WH, Hakimi MH, Yandoka BM, Mustapha KA, Aturamu AO (2014) Trace elements geochemistry of kerogen in Upper Cretaceous sediments, Chad (Bornu) Basin, northeastern Nigeria: origin and paleo-redox conditions. J Afr Earth Sci 100:675-683

Algeo TJ, Lyons TW (2006) Moetotal organic carbon covariation in modern anoxic marine environments: implications for analysis of paleoredox and paleohydrographic conditions. Paleoceanography 21:1016. https://doi.org/10.1029/2004pa001112

Algeo TJ, Maynard JB (2004) Trace-element behavior and redox facies in core shales of Upper Pennsylvanian Kansas-type cyclothems. Chem Geol 206:289-318

Algeo T, Tribovillard N (2009) Environmental analysis of paleoceanographic systems based on molybdenumeuranium covariation. Chem Geol 268:211-225

Angerera T, Kerrichb R, Steffen G (2013) Geochemistry of a komatiitic, boninitic, and tholeiitic basalt association in the Mesoarchean Koolyanobbing greenstone belt, Southern Cross Domain, Yilgarn craton: Implications for mantle sources and geodynamic setting of banded iron formation. Precambrian Res 224:110-128

Arning ET, Lückge A, Breuer C, Gussone N, Birgel D, Peckmann J (2009) Genesis of phosphorite crusts off Peru. Mar Geol 262:68-81

Baioumy HM, Tada R (2005) Origin of Upper Cretaceous phosphorites in Egypt. Cretac Res 26:261-275

Bea F (1996) Residence of REE, Y, Th and U in grantic and crustal protoliths: implications for the chemistry of crustal melts. J Petrol 37:521-528

Blumenberga M, Thiela V, Riegela W, Linda K, Joachim R (2012) Biomarkers of black shales formed by microbial mats, Late Mesoproterozoic (1.1 Ga) Taoudeni Basin, Mauritania. Precambrian Res 196-197:113-127

Brumsack HJ (2006) The trace metal content of recent organic carbonrich sediments: implications for Cretaceous black shale formation. Palaeogeogr Palaeoclimatol Palaeoecol 232:344-361

Delian FZ, Tao Y, Jie J, Yea B, Kribekc P, Dobesc P, Varrinc Zak K (2004) Geochemistry and origin of tin-polymetallic sulfide deposits hosted by the Devonian black shale series near Dachang, Guangxi, China. Ore Geol Rev 24:103-120

El-Shafeiy M, El-Kammar A, El-Barkooky A, Meyers Philip A (2016) Paleo-redox depositional conditions inferred from trace metal accumulation in two Cretaceous-Paleocene organic-rich sequences from Central Egypt. Mar Pet Geol 73:333-349
El-Shafeiy M, Birgel D, El-Kammar A, El-Barkooky A, Wagreich M, Tahoun S, Peckmann J (2017) Integrated palaeo-environmental proxies of the Campanian to Danian organic-rich Quseir section, Egypt. Mar Pet Geol. https://doi.org/10.1016/j.marpetgeo.2017 .06 .025

Fedo CM, Nesbitt HW, Young GM (1995) Unravelling the effects of potassium metasomatism in sedimentary rocks and paleosols, with implications for paleoweathering conditions and provenance. Geology 23:921-924

Fedo CM, Eriksson K, Krogstad EJ (1996) Geochemistry of shale from the Archean $(\sim 3.0 \mathrm{Ga})$ Buhwa Greenstone belt, Zimbabwe: implications for provenance and source area weathering. Geochem Cosmic Acta 60(10):1751-1763

Forster HJ (1998) The chemical composition of REE-Y-Th-U rich accessory minerals in peraluminous granites of the ErzgebirgeFichtelegebirge region, Germany, Part I: the monazite-(Ce)—brabantite solid solution series. Am Miner 83:259-272

Galarraga F, Reategui K, Martïnez A, Martínez M, Llamas JF, Márquez G (2008) V/Ni ratio as a parameter in palaeoenvironmental characterisation of non-mature medium-crude oils from several Latin American basins. J Petrol Sci Eng 61:9-14

Gallego-Torres D, Martinez-Ruiz F, De Lange GJ, Jimenez-Espejo FJ, Ortega-Huertas M (2010) Trace-elemental derived paleoceanographic and paleoclimatic conditions for Pleistocene Eastern Mediterranean sapropels. Palaeogeogr Palaeoclimatol Palaeoecol 293(1):76-89

Glenn C, Arthur A (1990) Anatomy and origin of a Cretaceous phosphorite green sand giant. Egyptian Sedimentol 37:132-154

Hetzel A, Brumsack H-J, Schnetger B, Bottcher ME (2006) Inorganic geochemical characterization of lithologic units recovered during ODP Leg 207 (Demerara rise). In: Mosher DC, Erbacher J, Malone MJ (eds.) Proceedings of the ocean drilling program, scientific results, vol 207, pp 1-37. College Station, TX (Ocean Drilling Program)

Hetzel A, Bottcher ME, Wortmann UG, Brumsack H-J (2009) Palaeoredox conditions during OAE2 reflected in demerara rise sediment geochemistry (ODP Leg 207). Palaeogeogr Palaeoceanogr Palaeoecol 273:302-328

Lee YI (2009) Geochemistry of shales of the Upper Cretaceous Hayang Group, SE Korea: implications for provenance and source weathering at an active continental margin. Sed Geol 215:1-12

Loukola-Ruskeeniemi K, Lahtinen H (2013) Multiphase evolution in the black shale hosted Ni-Cu-Zn-Co deposit at Talvivaara, Finland. Ore Geol Rev 52:5-99

Marz C (2007) Inorganic geochemical redox proxies-indicators for rapid palaeoenvironmental changes and related diagenetic processes in recent and ancient marine sediments ( $\mathrm{Ph} \mathrm{D}$ thesis), University of Bremen

McLennan SM, Hemming S, McDennial DK, Hanson GN (1993) Geochemical approaches to sedimentation, provenance and tectonics. Geol Soc Am Spec Pap 284:21-40

Nesbitt HW, Young GM (1982) Early Proterozoic climates and plate motion inferred from major element chemistry of lutites. Nature 299:715-717

Peters KE, Moldowan JM (1993) The biomarker guide: interpreting molecular fossils in petroleum and ancient sediments. PrenticeHall Inc, Englewood Cliffs

Pi DH, Jiang SY, Luo L, Yang JH, Hong-Fei Ling HF (2014) Depositional environments for stratiformwitherite deposits in the Lower Cambrian black shale sequence of the Yangtze platform, southern Qinling region, SW China: evidence from redox-sensitive trace element geochemistry. Palaeogeogr Palaeoclimatol Palaeoecol 398:125-131

Piper DZ (1994) Seawater as the source of minor elements in black shales, phosphorites and other sedimentary rocks. Chem Geol 114:95-114 
Quinby-Hunt MS, Wilde P (1994) Thermodynamic zonation in the black shale facies based on iron-manganese-vanadium content. Chem Geol 113:297-317

Ross DJK, Bustin RM (2009) Investigating the use of sedimentary geochemical proxies for palaeoenvironment interpretation of thermally mature organic-rich strata: examples from the Devonian-Mississippian shales, Western Canadian Sedimentary Basin. Chem Geol 260:17-19

Rudnick RL, Gao S (2003) Composition of the continental crust. Treatise Geochem 3:1-64

Schieber J, Baird G (2001) On the origin and significance of pyrite spheres in Devonian black shale of North America. J Sediment Res 71(1):155-166

Schneider-Mor A, Alsenz H, Ashckenazi-Polivoda S, Illner P, Abramovich S, Feinstein S, Almogi-Labin A, Berner Z, Püttmann W (2012) Paleoceanographic reconstruction of the late Cretaceous oil shale of the Negev, Israel: integration of geochemical, and stable isotope records of the organic matter Palaeogeography. Palaeoclimatol Palaeoecol 319-320:46-57

Singer A (1980) The Paleoclimatic interpretation of clay minerals in soils and weathering profiles. Earth Sci Rev 15:303-326

Singh M, Sharma M, Tobschall HL (2005) Weathering of the Ganga alluvial plain, northern India: implications from fluvial geochemistry of the Gomati River. Appl Geochem 20:1-21
Smrzka D, Zwicker J, Kolonic S, Birgel D, Little CTS, Marzouk AM, Chellai EH, Wagner T, Peckmann J (2017) Methane seepage in a Cretaceous greenhouse world recorded by an unusual carbonate deposit from the Tarfaya basin, Morocco. Depositional Rec. http s://doi.org/10.1002/dep2.24 (in press)

Swanson V (1961) A review geology and geochemistry of Uranium in Marine Black Shales. United States Government Printing Office, Washington, $\mathrm{p} 112$

Taylor SR, McLennan SM (1985) The continental crust: its composition and evolution. Blackwell, Oxford, pp 46-92

Tribovillard N, Algeo TJ, Lyons T, Riboulleau A (2006) Trace metals as paleoredox and paleoproductivity proxies: an update. Chem Geol 232:12-32

Turekian KK (1978) Nickel. In: Wedepohl KH (Ed.), Handbook of geochemistry, II/3. Springer, Berlin, 28-K-1-28-L-3

Xiugen Fu, Wang Y, Zeng F, Tan E, Feng X (2010) REE geochemistry of marine oil shale from the Changshe Mountain area, northern Tibet, China. Int J Coal Geol 81:191-199

Yoffe O, Nathan Y, Wolfarth A, Cohen S, Shovel S (2002) The chemistry and mineralogy of the Negev oil shale ashes. Fuel 88:1101-1117

Yuretich R, Melles M, Starata B, Grobe H (1999) Clay minerals in the sediments of Lake Baikal: a useful climate proxy. J Sediment Res 69(3):588-896 